B. Varga; B. Mikó, Budapest, Hungary

\title{
THE EFFECT OF THE POINT SAMPLING TO THE RESULT OF COORDINATE MEASURING OF FREE-FORM SURFACE
}

\begin{abstract}
The coordinate measuring technique appropriates to measure dimensional and geometric properties of a machine part. The result of the measuring is effected by several parameters, like the measuring method, the point sampling technique, and the mathematical processing of the measured coordinates. The current article investigates the effect of the point sampling methods in case of a freeform surface. Two methods are compared: the uniform matrix method, and the Halton-Zaremba quasirandom method. The number of measured points is investigated also. The free-form test surface was produced by ball-end milling, and the radius, the cylindricity and the surface profile error were assessed.
\end{abstract}

Keywords: free-form milling; geometric tolerances; point sampling; form deviation.

\section{INTRODUCTION}

The free-form surfaces are widely used in die and mould industry. The accuracy of the surfaces is critical in this application, because the shape of the mould is copied to the product. The geometric accuracy of the free-form surface is the result of the cutting technology, but the measuring method ensures the feedback to the production.

The coordinate measuring technique appropriates to measure dimensional and geometric properties of a machine part. The measuring process is defined by several parameters and circumstances, which have effect on the measured results. The measuring method (contact or non-contact), the point sampling method, the mathematical method of the data processing are the most characteristic questions in case of coordinate measuring of free-form surfaces [1].

During the point sampling, the number of measured points a distribution of them are defined. Regular, random, quasi-random and adaptive point sampling method can be used.

Kawalecz and Magdziak [2] investigates the accuracy of the curve reconstruction in function of the number of measured points. The numerical simulation shown, than the accuracy do not change over 50 points. Zhao et al. [3] investigates the similar approach in case of four case studies. They found, that over 50 points, the deviation of the theoretical and constructed surface decreases.

Zahmati et al. [4] suggest a new adaptive point sampling method, which consider the CAD model of the free form surface. The positions of the points are determined by a swarm algorithm. Rajamohan et al. [5] investigates uniform and adaptive point distribution methods. In case of 25 points, the patch size ranking 
method ensured the smallest error of the rebuild surface.

The aim of the research is to investigate the effect of the tool path strategies of ball-end milling on the micro and macro accuracy of a free form surface. During the research not only the machining circumstances, but also the selection of the appropriate measuring methods means challenges. The detailed definition of the measuring method is important from the viewpoint of the accuracy of the result, the comparison of the different parts, and the time of the measuring process.

In this paper, the coordinate measuring method is analysed. The aim of the paper is to present the effect of the point sampling methods and the number of measure points (NoP) on the dimensional and geometric error in case of free form surface. The results will be the base of the measuring process of the further research for investigate the effect of the tool path and the cutting parameters to the dimensional and geometric accuracy.

\section{Materials and methods}

Four convex $(\mathrm{CX})$ and four concave $(\mathrm{CV})$ test parts were manufactured by ball-end milling. The radius of the cylindrical test surface was $45 \mathrm{~mm}$. The overall size of the test part is $80 \times 80 \mathrm{~mm}$. The material of the part was 42CrMo4 (1.7225; $\mathrm{Rm}=1000 \mathrm{MPa}$ ) low alloy steel. The four teeth ball-end milling cutter was used with $10 \mathrm{~mm}$ diameter, the tool was Fraisa X7450.450 solid carbide milling cutter.

The machining was performed by a Mazak 410 A-II CNC machining centre, and the CNC programs were generated by CATIA v5 CAD/CAM systems. The tool path was parallel with the $y$-axis, and the zigzag strategy was used. The spindle speed (n) was $5100 \mathrm{1} / \mathrm{min}$, the depth of cut $\left(a_{\mathrm{p}}\right) 0.3 \mathrm{~mm}$. The feed per tooth $\left(f_{z}\right)$, the feed speed $\left(v_{f}\right)$ and the width of cut $(a e)$ were varied based on the Table 1 .

Table 1 - The cutting parameters

\begin{tabular}{|l|l|l|l|l|l|}
\hline & $\begin{array}{l}\mathrm{n} \\
1 / \mathrm{min}\end{array}$ & $\begin{array}{l}\mathrm{f}_{\mathrm{z}} \\
\mathrm{mm}\end{array}$ & $\begin{array}{l}\mathrm{v}_{\mathrm{f}} \\
\mathrm{mm} / \mathrm{min}\end{array}$ & $\begin{array}{l}\mathrm{a}_{\mathrm{p}} \\
\mathrm{mm}\end{array}$ & $\begin{array}{l}\mathrm{a}_{\mathrm{e}} \\
\mathrm{mm}\end{array}$ \\
\hline CV-1 & 5100 & 0.08 & 1630 & 0.3 & 0.35 \\
\hline CX-1 & 5100 & 0.08 & 1630 & 0.3 & 0.35 \\
\hline CV-2 & 5100 & 0.08 & 1630 & 0.3 & 0.25 \\
\hline CX-2 & 5100 & 0.08 & 1630 & 0.3 & 0.25 \\
\hline CV-3 & 5100 & 0.12 & 2450 & 0.3 & 0.15 \\
\hline CX-3 & 5100 & 0.12 & 2450 & 0.3 & 0.15 \\
\hline CV-4 & 5100 & 0.16 & 3260 & 0.3 & 0.15 \\
\hline CX-4 & 5100 & 0.16 & 3260 & 0.3 & 0.15 \\
\hline
\end{tabular}

The coordinates of the surface points were measured by the Mitutoyo CrystaPlus 544 coordinate measuring machine. The 441 points were measured in an 
equidistant, $21 \times 21$ matrix. During the analyses, the current point pattern was generated by the selection of these points.

Two point sampling methods were investigated, the uniform matrix pattern (maked by $\mathrm{X}$ ) and the Halton-Zaremba method (marked by HZ). The uniform matrix pattern covers the whole surface with the same point density. However, in case of low number of points, some regions are not covered exactly. The problem is, that the character of the surface should be consider during determining the point pattern, but then the preliminary processing of the investigated surface is required. The quasi-random methods, like the Halton-Zaremba pattern, cover the surface with better sampling. The random point patterns eliminate the problems of periodical errors also.

In case of Halton-Zaremba method the relative coordinates of the point can be defined as following [6]:

$$
\begin{gathered}
x_{i}=\frac{i}{N o P} \\
y_{j}=\sum_{j=0}^{k-1} b_{i j}{ }^{\prime} \cdot 2^{(-j-1)}
\end{gathered}
$$

where

$i$ : the number of the points ( $O$ to $(N o P-1))$

$b_{i j}$ : the $j^{\text {th }}$ bit of the binary representation of $i$

$b_{i j}$ ': the transformed value of $b_{i j}$

$b_{i j}^{r}=b_{i j}$, if $j$ is even,

$b_{i j}^{\prime}=1-b_{i j}$, if $j$ is odd,

For example, if 36 points were determined $(N o P=36)$ the $i$ is between 0 and 35 . The binary representation of $i=35$ and the $b_{i j}$ ' are:

\begin{tabular}{|c|c|c|c|c|c|c|}
\hline $\boldsymbol{j}$ & 5 & 4 & 3 & 2 & 1 & 0 \\
\hline $\boldsymbol{b}_{\boldsymbol{i j}}$ & 1 & 0 & 0 & 1 & 0 & 0 \\
\hline $\boldsymbol{b}_{\boldsymbol{i j}} \boldsymbol{\gamma}$ & 0 & 0 & 1 & 1 & 1 & 0 \\
\hline
\end{tabular}

Fig. 1 shows the 36 points in case of concave and convex test parts. The first picture shows the uniform matrix pattern, and the second shows the HaltonZaremba pattern. In case of matrix pattern, there are several points on the horizontal sections, but no points on the small radius. In case of the HaltonZaremba pattern, there are points on every regions.

The number of measured points were NoP $=16,25,36,49,64,100,121$. The seven matrix patterns and Halton-Zaremba patterns are shown on the fig. 2 and fig. 3 . During the research two types of surface were investigated $(\mathrm{CV} / \mathrm{CX})$, which were machined by 4 different sets of parameters, 7 sets of points were measured based on 2 patterns, so the number of data was $2 \times 4 \times 7 \times 2=112$. 


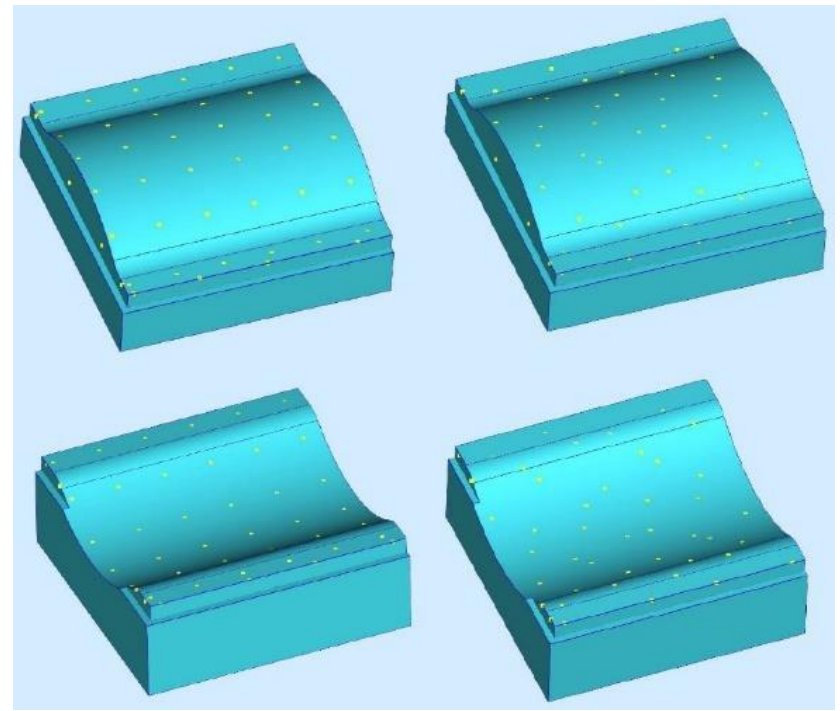

Figure 1 - Example for point sampling in case of 36 points
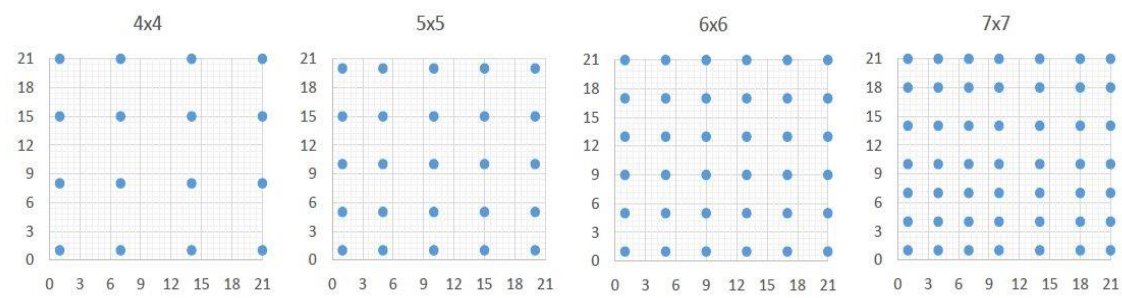

$8 \times 8$

$10 \times 10$

$11 \times 11$
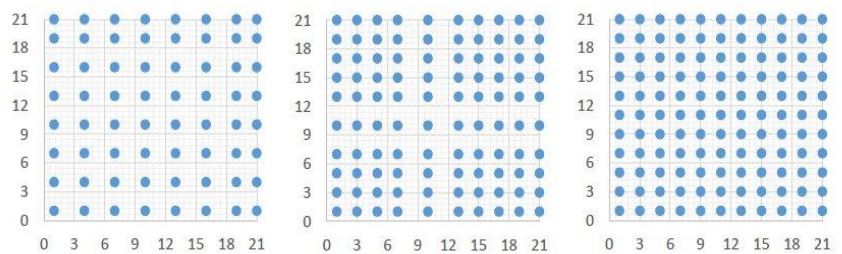

Figure 2 - Matrix point sampling patterns 

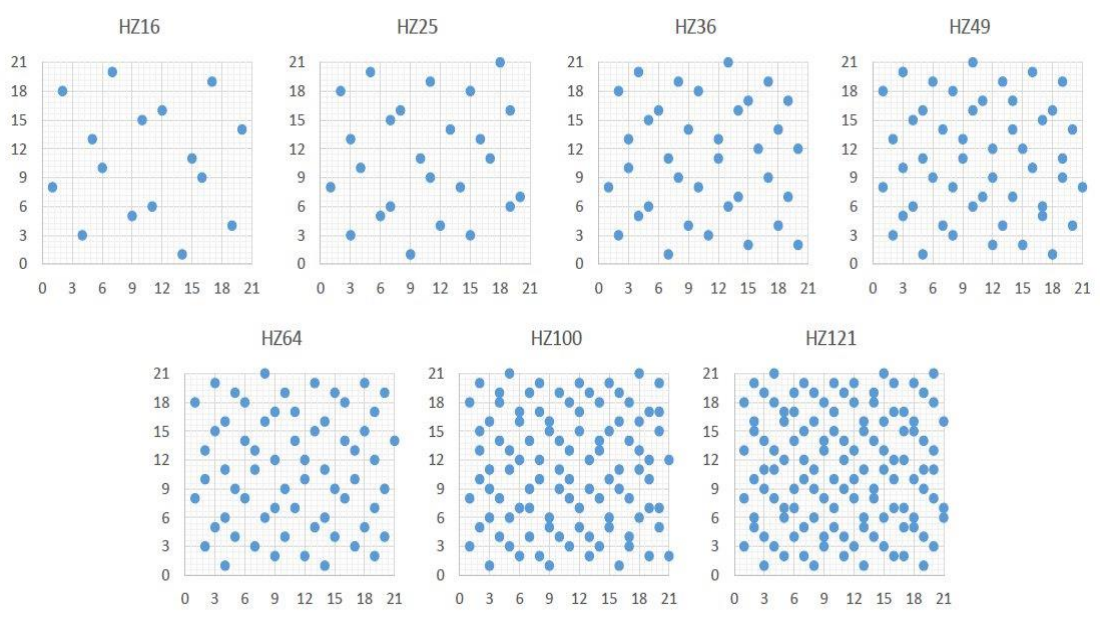

Figure 3 - Halton-Zaremba point sampling patterns

Based on the measured point data the radius of the cylindrical surface (R), the cylindricity error (Cyl) and the surface profile error of the whole surface (SP) were determined. The reference values are the result of the evaluation of 441 points. The dimensional and geometric error were determined by Evolve Smart Profile v7. The data analysis was performed by Excel and MiniTab v14.

\section{Results}

The measured data of the radius, cylindricity error and surface profile error in function of number of measured points can be seen on the fig. 4 . The value of the radius is very different in case of convex and concave parts $(\sim 0.09-0.14 \mathrm{~mm})$ and in case of small number of points, the value is inaccurate, the changing is large. The HZ pattern ensures better stability of the evaluated radius, while the matrix pattern results very different radius comparing with the reference values.

In case of geometric errors, the effect of the nature of the surface is smaller, but the importance of the number of measured point is evident. Small number of measured points result smaller geometric error, but the $\mathrm{HZ}$ patterns reach the near reference value earlier. Based on the diagrams the point number 49 is the lower limit in case of the investigated geometry.

The effect of the measuring pattern can be seen on the error map also. Fig. 5 shows the four error maps of surface profile error in case of 36 measured points. The left pictures show the result of the matrix pattern and the right ones show the 
maps of the Halton-Zaremba method. In case of matrix pattern, there is no point on the small radiuses, so it cannot be taken into account.

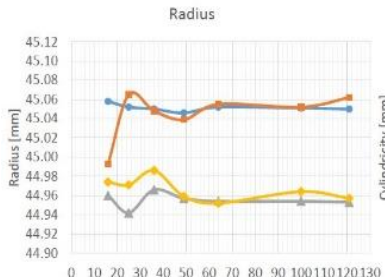
Number of points

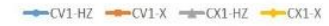

Radius

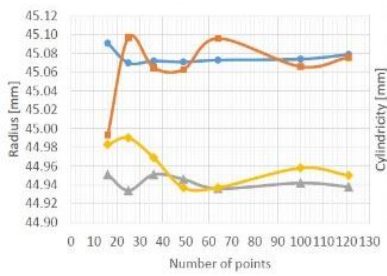

$\rightarrow \mathrm{CV}_{2} \mathrm{HZ} \rightarrow-\mathrm{CV}_{2}-\mathrm{X} \rightarrow \mathrm{CX}_{2}-\mathrm{HZ} \rightarrow \mathrm{CX}_{2} \mathrm{X}$

Radius

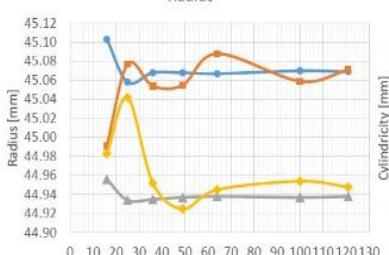
Number of points
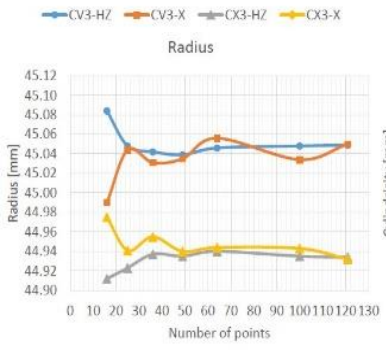

$\rightarrow \mathrm{CV} 4 \cdot \mathrm{HZ} \rightarrow \mathrm{CV} 4-\mathrm{X}+\mathrm{CX} 4-\mathrm{HZ}=\mathrm{CX} 4-\mathrm{X}$
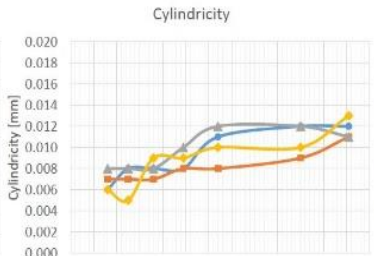

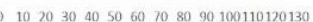
Number of points

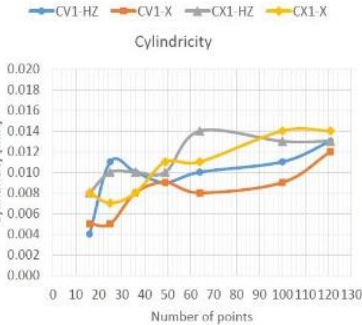
Number of points

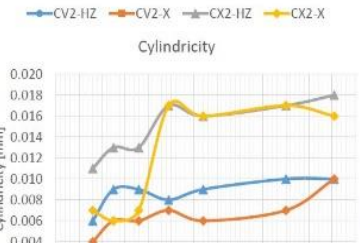

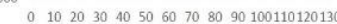
Number of points
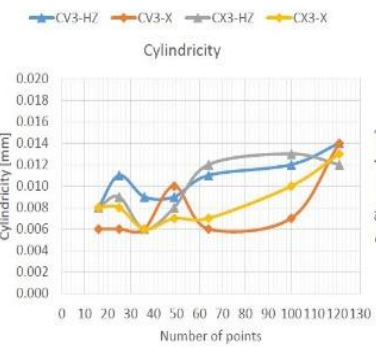

$\pm \mathrm{CV}_{4}-\mathrm{HZ} \leftrightarrow \mathrm{CV} 4-\mathrm{X} \leadsto \mathrm{CX} 4-\mathrm{HZ} \leadsto \mathrm{CX} 4-\mathrm{X}$

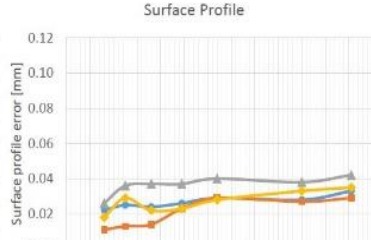

0.00

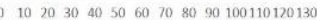
Number of points

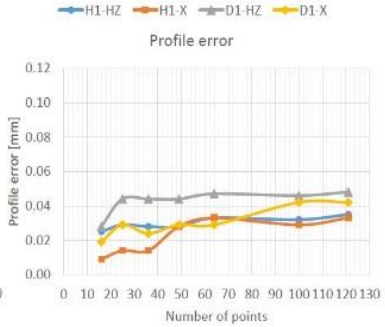

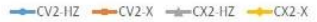

Profile error

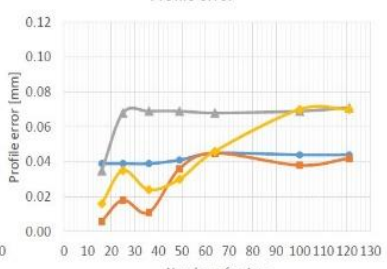
Number of points
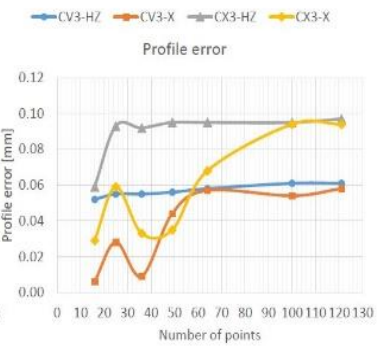

$\rightarrow \mathrm{CV} 4-\mathrm{HZ}_{2} \rightarrow \mathrm{CV} 4-\mathrm{X} \leadsto \mathrm{CX} 4-\mathrm{HZ} \leadsto \mathrm{CX}_{4}-\mathrm{X}$

Figure 4 - The measured dimensional and geometric data 


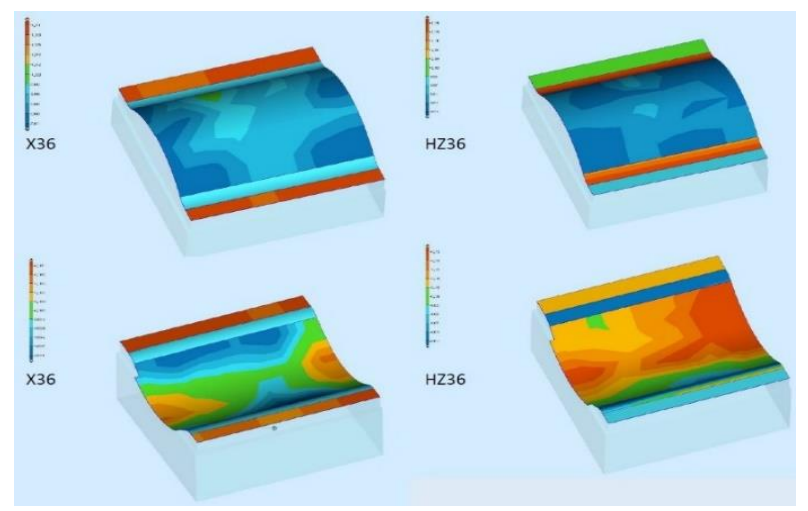

Figure 5 - The surface profile error in case of $\mathrm{NoP}=36(\mathrm{CX}-1 ; \mathrm{CV}-1)$

In order to deeper analysis of the factors, main effect plots were generated. The main effect plot shows the average value of the investigated parameter, in function of the selected input parameter.

Fig. 6 shows the results of the analysis of the value of the radius. The rR means the ratio of the measured and the reference value. The ideal value is one, when the measured value is equal with the reference value.

The character of the surface has the largest effect on the radius, the cutting parameter sets, the number of points and the point sampling method has just a little effect. Nevertheless, in case of convex and concave surfaces the values of the radius are very different, the average values can balance each other, so the separated database was analysed too (fig. 7). In these cases, the effect of the number of points is well recognised. The value of the radius approaches the reference value. The effect of the point sampling method is clearer: the HaltonZaremba method ensures more accurate results.
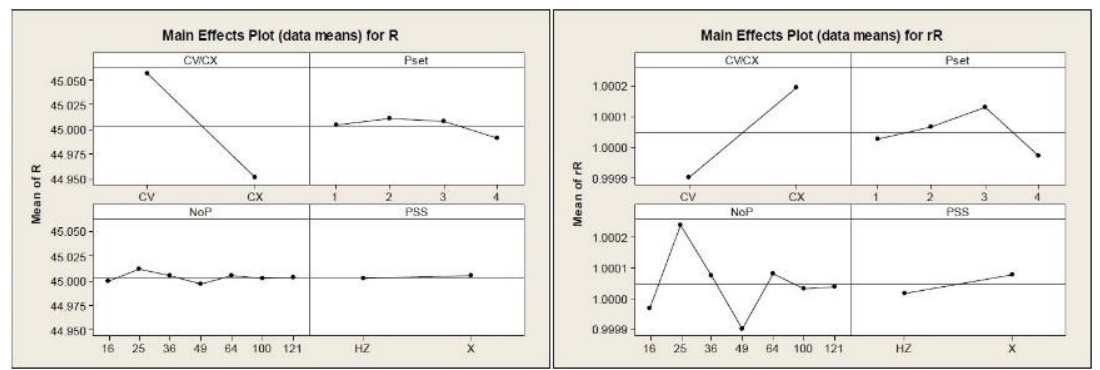

Figure 6 - The main effect plots of the radius 
ISSN 2078-7405 Cutting \& Tools in Technological System, 2022, Edition 96
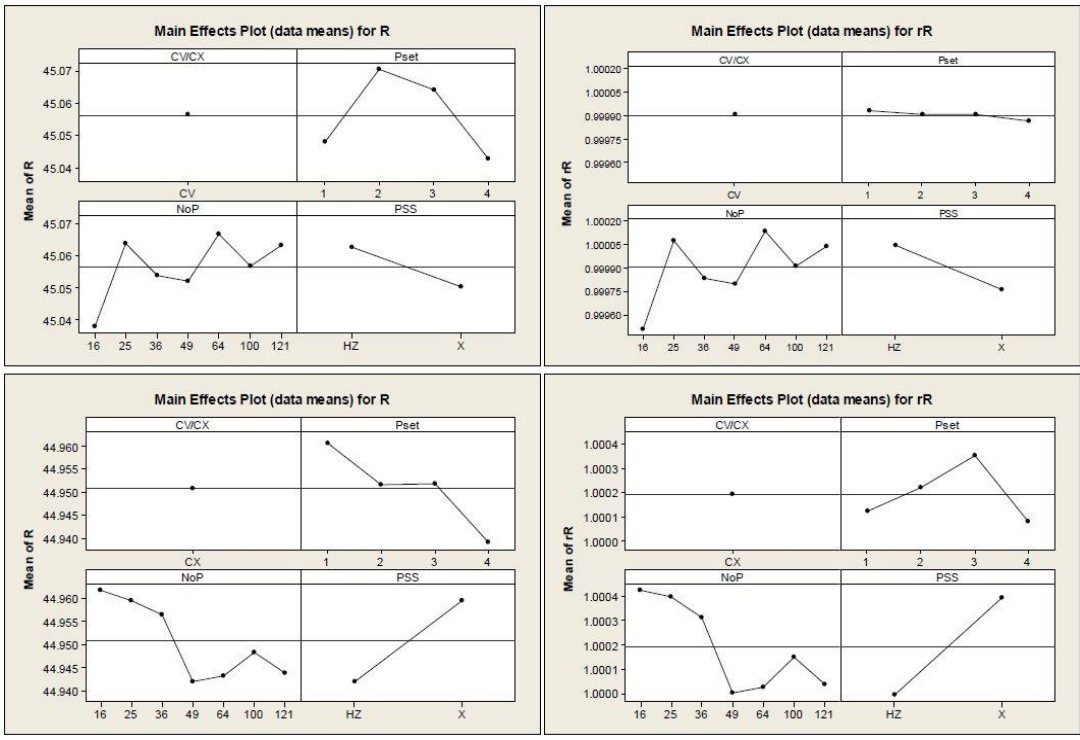

Figure 7 - The main effect plots of the radius in case of separated data
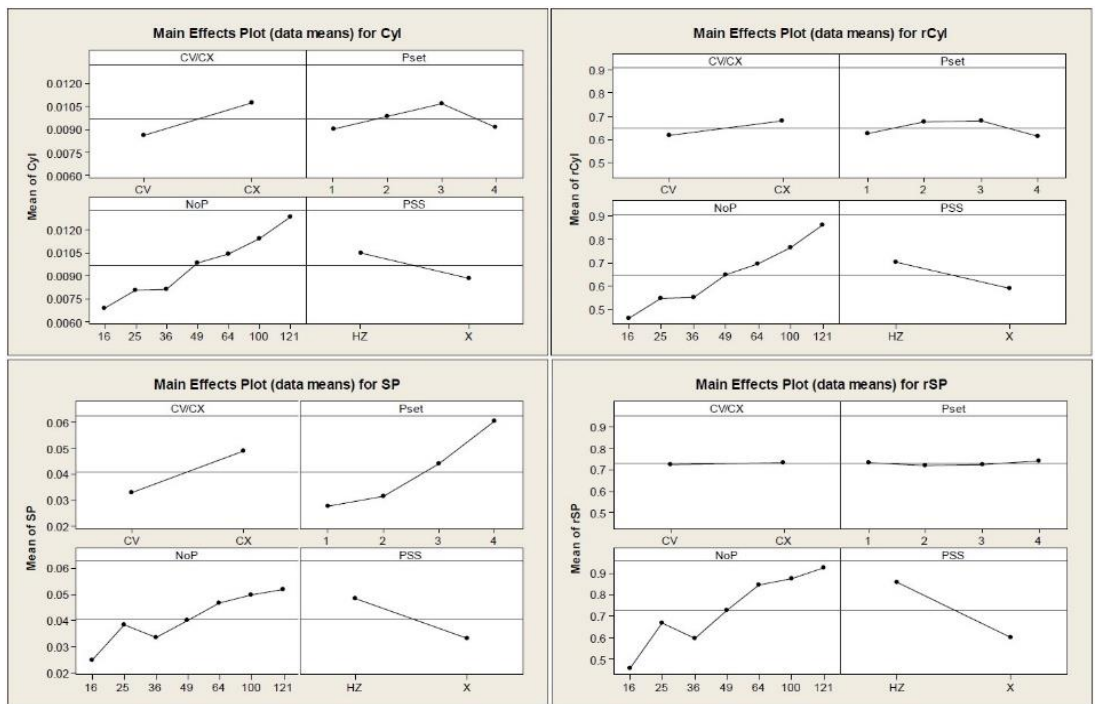

Figure 8 - The main effect plots of the geometric errors 
The main effect plots of the cylindricity and the surface profile error show (fig. 8), that the character of the surfaces has effect on the geometric error. The convex surfaces have smaller error, but in case of relative values, the effect is small. The number of measured points improves the results. The cylindricity and the surface profile error are close to the reference values. However the cutting parameters modify the geometric errors, they have no effect on the relative values. The Halton-Zaremba point sampling method ensures more accurate results in this case too.

\section{Conclusion}

The geometric errors are receiving increasing attention in the machine and tool design and manufacturing. During the tolerancing process, not only the functional and manufacturing aspects have to be considered, but the measuring process also. The parameters of the measuring process have effect on the results, so the standard measuring process ensures the repeatability and comparability.

The effect of the number of measured points and the point sampling method were investigated in case of free form surface milling. Two methods were compared, the uniform matrix method and the Halton-Zaremba quasi-random method.

In case of the dimensional error (value of the radius), the number of points and the point sampling method have only a little effect on the measured values.

In case of cylindricity and surface profile error, the character of the surface (convex or concave) and the cutting parameters have no effect on the relative values of the errors. The increasing number of points correct the values and the Halton-Zaremba method ensures better results.

Based on the measured data, under 49 points, the results can change a lot. Therefore, the 49 points can be a lower limit of the number of measured points with Halton-Zaremba pattern in case of the test geometry.

The regression analysis [7] can improve the accuracy of the assessment of the geometric error, so the further aim is to apply this method in case of surface profile error of free form surfaces.

References: 1. Li Y; Gu P. (2004) Free-form surface inspection techniques state of the art review. Computer-aided design 36:1395-1417 doi: 10.1016/j.cad.2004.02.009. 2. Kawalec A; Magdziak M. (2011) An influence of the number of measurement points on the accuracy of measurements of freeform surfaces on CNC machine tool. Advances in Manufacturing Science and Technology 35(2):17-27. 3. Zhao D; Wang W.; Zhou J.; Jiang R.; Cui K.; Jin Q. (2018) Measurement point sampling method for inspection of parts with free-form surfaces. Advances in Mechanical Engineering 10(11):1-12 doi: 10.1177/1687814018809577. 4. Zahmati J.; Amirabadi H.; Mehrad V. (2018) A hybrid measurement sampling method for accurate inspection of geometric errors on freeform surfaces. Measurement 122:155-167 doi: 10.1016/j.measurement.2018.03.013. 5. Rajamohan G.; Shunmugam M.S.; Samuel G.L. (2011) Practical measurement strategies for verification of freeform surfaces using coordinate 
measuring machines. Metrology and Measurement Systems 18(2):209-222 doi: 10.2478/v10178-0110004-y. 6. Moroni G, Petro S. (2011) Coordinate measuring machine measurement planning. Colosimo B, Senin N (eds) Geometric Tolerances. Springer, London pp.111-158 doi: 10.1007/978-1-84996-3114_4. 7. Mikó B. (2021) Assessment of flatness error by regression analysis. Measurement 171:108720 doi: 10.1016/j.measurement.2020.108720.

\title{
Балінт Варга, Балаш Міко, Будапешт, Угорщина
}

\section{ВПЛИВ ТОЧКОВОЇ ВИБІРКИ НА РЕЗУЛЬТАТ КООРДИНАТНИХ ВИМІРЮВАНЬ ПОВЕРХНІ ДЕТАЛІ ДОВІЛЬНОЇ ФОРМИ}

\begin{abstract}
Анотація. Координатно-вимірювальна техніка призначена для вимірювання розмірних та геометричних параметрів деталей машини. На результат вимірювання впливають кілька параметрів, таких як метод вимірювання, метод вибірки точок та математичне оброблення вимірюваних координат. У иій статті досліджується вплив методів точкового відбору проб у випадку поверхні вільної форми. Порівнюються два методи: метод однорідних матриць та квазівипадковий метод Холтона-Заремби. Досліджується також кількість точок, щя вимірюваються. Випробувана поверхня довільної форми була виготовлена за допомогою ториевого фрезерування, $і$ були очінені радіус, ииліндричність та похибка профілю поверхні. Геометричним похибкам приділяється все більше уваги при проектуванні та виробництві машин та інструментів. У процесі визначення допусків необхідно враховувати як функціональні $i$ виробничі аспекти, так $і$ процес виміру. Параметри прочесу вимірювання впливають на результати, тому що стандартний процес вимірювання забезпечує відтворюваність та сумісність. У разі розмірної помилки (значення радіусу) кількість точок та метод вибірки точок мало впливають на виміряні значення. У разі помилки ииліндричності та профілю поверхні, характер поверхні (опукла або увігнута) та параметри різання не впливають на відносні значення помилок. Збільшення кількості точок коригує значення, а метод ХолтонаЗаремби забезпечує найкращі результати. На основі виміряних даних, менше 49 балів результати можуть сильно змінитися. Таким чином, 49 точок можуть бути нижньою межею кількості виміряних точок з діаграмою Холтона-Заремби у разі тестової геометрії. Регресійний аналіз може підвищити точність очінки геометричної похибки, тому метою є застосування иього методу у разі похибки профілю поверхонь довільної форми.
\end{abstract}

Ключові слова: фрезерування довільної форми; геометричні допуски; точковий відбір проб; відхилення форми. 